\section{Ranah Sumber Konseptualisasi Kemenangan Pascapemilihan Presiden dan
Wakil Presiden Tahun 2019
dalam Media Sosial Twitter}

\begin{abstract}
ABSTRAK
Metafora konseptual merupakan bentuk kebahasaan berupa ekspresi linguistik yang digunakan sebagai alat untuk melihat dan memahami sesuatu. Hal tersebut berhubungan erat dengan bahasa dan pikiran tidak dapat dipisahkan dalam kehidupan sehari-hari. Penelitian ini dilator belakangi oleh pemetaan pola pikir masyarakat tentang kemenangan pascapemilihan Presiden dan Wakil Presiden Indonesia tahun 2019 dalam media sosial twitter. Adanya konseptualisasi dari satu masyarakat dengan masyarakat lain mengenai konsep kemenangan merupakan hasil dari cara berpikir secara kognitif. Masyarakat membangun konsep abstrak berupa kemenangan dalam media sosial twitter, dengan konsep lain yang lebih konkret atau biasa disebut dengan ranah sumber. Penelitian ini bertujuan untuk mendeskripsikan ranah sumber pada konseptualisasi kemenangan pascapemilihan. Data dalam penelitian ini diambil dari cuitan (tweet) masyarakat Indonesia yang menggunakan media sosial twitter mengenai kemenangan. Pengambilan data dibatasi pascapemilihan dari tanggal 17 April 2019 hingga 30 Juni 2019. Berdasarkan pengamatan dan analisis data, hasil penelitian menunjukkan bahwa masyarakat Indonesia memetakan metafora kemenangan dalam berbagai konseptualisasi yang diwujudkan melalui ranah sumber. Berdasarkan 112 data yang telah dianalisis, selanjutnya diklasifikasikan menjadi sembilan ranah sumber metafora kemenangan, yaitu (1) manusia; (2) bangunan; (3) makanan; (4) cahaya; (5) alat; (6) permainan dan pertandingan; (7) perjalanan;(8) harta; dan (9) agama. Intensitas data didominasi oleh ranah sumber manusia serta permainan dan pertandingan, sedangkan intensitas yang paling sedikit ranah sumber agama dan bangunan.
\end{abstract}

Kata Kunci: metafora, metafora konseptual, ranah sumber, kemenangan

\title{
PENGANTAR
}

Bahasa dan pikiran memiliki keterkaitan yang berjalan beriringan. Bahasa sebagai tindakan komunikasi verbal secara lisan maupun tertulis, sedangkan pikiran didefinisikan sebagai peristiwa mental berupa proses dan mekanisme penyusunan persepsi konsep sampai atau tidak menjadi pengetahuan personal atau pengetahuan bersama (Arimi, 2015:3). Dalam ilmu linguistik, bahasa dan pikiran dikaji secara khusus melalui linguistik kognitif. Salah satu bagian yang menarik dalam linguistik kognituf adalah metafora konseptual.

Umumnya, metafora dikenal sebagai wujud penggunaan bahasa yang tertulis atau digunakan secara puitis, tanpa mengesampingkan keterkaitan antara bahasa dan pikiran. Namun, seperti pada pernyataan sebelumnya, tanpa kita sadari ternyata metafora erat kaitannya dengan sistem konseptual manusia, dalam bentuk dan bertindak, secara mendasar dan bersifat metaforis (Lakoff dan Johnson, 2003). Metafora dapat ditemui di mana-mana tanpa disadari dan berfungsi sebagai alat untuk memahami satu konsep ke konsep yang lain.

Lakoff dan Johson (2003) juga menjelaskan bahwa semua ungkapan metafora dikategorikan sebagai metafora knseptual, karena dalam metafora suatu pengalaman selalu dijelaskan dengan menggunakan pengalaman yang lain. Selain itu, Kovecses (2010) mendefinisikan metafora sebagai sebuah property kata-kata yang termasuk dalam fenomena linguistik. Adanya penggunaan metaforis oleh seseorang atau kelompok masyarakat merupakan sebuah karakteristik yang berasal dari 
ekspresi linguistik. Bahkan, metafora juga dapat digunakan untuk mengidentifikasi tujuan tertentu dan menjelaskan dari sesuatu yang abstrak ke sustau yang konkret. Deskripsi metafora sebagai sesuatu yang didasarkan pada kemiripan antara dua entitas atau dua konsep yang dibandikan dan diidentifikasi dalam konsep tertentu.

Metafora sebagai sebuah pemikiran yang digunakan untuk mengkonsepkan suatu hal ke hal lain. Arimi (2015:126) menjelaskan bahwa metafora konseptual merupakan satuan ekspresi kebahasaan yang memiliki satu konsep yang dipetakan dengan satuan ekspresi kebahasaan lain yang memiliki satu konsep lain. Pemetaannya mencakup satu ranah sumber dan satu ranah sasaran. Hal tersebut membuktikan bahwa metafora bukan tentang keindahan dalam berbahasa saja, tetapi dapat digunakan untuk mengetahui pemetaan pemikiran yang digunakan oleh seseorang atau sekelompok dalam mengkonsepkan suatu hal.

Konseptualisasi mengenai kemenangan juga dinyatakan sangat beragam oleh masyarakat Indonesia. Pemilihan Presiden dan Wakil Presiden Indonesia tahun 2019 menghadirkan dua kandidat, yaitu Paslon 01 (Joko Widodo dan Ma'aruf Amin) dan Paslon 02 (Prabowo dan Sandiaga Uno). Kedua kadidat tersebut memiliki pendukung yang sama-sama kuat. Setelah pemilihan dilakukan pada 17 April 2019, tepatnya malam hari usai pelaksanaan pencoblosan ada beberapa keberagaman keyakinan yang muncul. Sebanyak lima lembaga hitung cepat (quick count) menyatakan kemenangan untuk Paslon 01 sebagai Presiden dan Wakil Presiden 2019-2024. Perolehan hitung cepat dari kelima lembaga tersebut, ternyata tidak mempengaruhi keyakinan pendukung Paslon 02 untuk mendeklarasikan kemenangan satu hari setelah pemilu, 18 April 2019. Bahkan, Badan Pemenangan Nasional (BPN) Prabowo-Sandi mengatakan bahwa Paslon o2 lebih unggul dari lawannya dan menganggap bahwa hasil hitung cepat kelima lembaga survei nasional tersebut tidak benar.

Adanya asumsi dan persepsi yang berbeda dari keduabelah pihak, mengakibatkan munculnya perbedaan dalam pola pikir masyarakat mengenai konsep kemenangan. Masyarakat menganggap kemenangan secara beragam dan menuliskannya dalam media sosial twitter. Cuitan (tweet) yang dituliskan oleh masyarakat menanggapi kemenangan yang dikonsepkan berbeda-beda juga sebagai wujud aktif masyarakat untuk berpendapat. Penggunaan media sosial twitter sebagai sarana komunikasi langsung (real time), menjadi media yang up to date digunakan untuk melihat pemikiran masyarakat Indonesia pascapemilihan.

(a) Sudahlah gak usah caper atau menjilat, masih banyak orang di TKN \& koalisi 01 yg pantas mendapat kue kemenangan.

(b) Kemenangan sudah terang benderang.

Dua data (a) dan (b) di atas merupakan contoh metafora kemenangan yang dituliskan oleh masyarakat dalam media sosial twitter. Cuitan tersebut merupakan bentuk dari pemikiran masyarakat mengenai konsep kemenangan yang konsepkan dengan sesuatu di sekitarnya. Dalam contoh data (a), kemenangan dimetaforkan dengan kue yang merupakan konseptualisasi dari makanan, sedangkan contoh data (b) kemenangan dimetaforkan dengan sesuatu yang sudah terang benderang yang merupakan konseptualisasi dari cahaya. Metafora kue kemenangan dan kemenangan sudah terang benderang merupakan ungkapan masyarakat Indonesia pengguna media sosial twitter berdasarkan apa yang mereka pikirkan.

Studi mengenai metafora pendidikan yang ditulis oleh Yonatri (2016) berjudul "Metafora Konseptual tentang Pendidikan dalam Bahasa Inggris" berfokus pada cara penutur bahasa Inggris memandang konsep pendidikan berdasarkan tuturan yang diproduksi. Data yang digunakan dalam penelitian tersebut berupa ungkapan metaforis yang mengandung konsep pendidikan oleh tokoh-tokoh penting dari berbagai latar belakang profesi yang berbeda. Hasil penelitian tersebut berupa realisasi mengenai konseptualisasi pendidikan oleh penutur bahasa Inggris. Ranah sumber dalam metafora pendidikan diklasifikasi menjadi 14, yaitu alat, uang dan bisnis, bangunan, manusia, makanan dan minuman, tumbuh-tumbuhan, cahaya, seni, perjalanan, kekuatan, sesuatu yang menyehatkan, lingkungan alam, permainan dan pertandingan, dan agama. Selain ranah sumber, penelitian tersebut juga menjelaskan mengenai korespondensi metaforis yang terbentuk antara ranah sasaran dan ranah sumber dalam metafora pendidikan. 
Penelitian mengenai metafora dalam bidang politik juga sudah pernah dilakukan sebelumnya. Arifiani (2015) dengan penelitian yang berjudul "Metafora dalam Wacana Politik: Studi Kasus Pemilihan Presiden dan Wakil Presiden Republik Indonesia Tahun 2019 di Majalah Tempo dan Surat Kabar Kompas". Fokus penelitian tersebut yaitu pada analisis wacana politik yang mengacu dalam peristiwa selama pemilihan Presiden dan Wakil Presiden Republik Indonesia Tahun 2019. Hasil dari penelitian tersebut mencakup deskripsi mengenai jenis metafora (metafora langsung, metafora tidak langsung, dan metafora implisit), ranah sasaran, ranah sumber, konseptualisasi metafora, dan fungsi bahasa yang melekat dalam metafora tersebut. Dalam penelitian tersebut ranah sasarannya tidak dibatasi sehingga terdapat 11 ranah sasaran, yaitu perebutan kekuasaan, tujuan politik, partai politik, relasi presiden dengan cabinet, presiden, negara, bangsa, cabinet, kementrian, pemerintahan, dan demokrasi. Lalu, ranah sumbernya diklasifikasi menjadi 16, yaitu perang, olahraga, pertunjukan sandiwara, permainan, manusia, hewan, perdagangan dan bisnis, perjalanan, kompetisi, mesin, keluarga, suhu, masakan, bangunan, transportasi, dan relasi suami-istri.

Selain penelitian di atas, Mudrika (2016) juga meneliti topik metafora mengenai politik yang berjudul "Penggunaan Metafora dalam Wacana Pemilihan Presiden Amerika Serikat Tahun 2012 Pada Surat Kabar The New York Times". Penelitian yang bertujuan untuk melihat penggunaan metafora dalam wacana pemilihan presiden Amerika Serikat tahun 2012 tersebut mengidentifikasi data menggunakan model Metaphor Identification Procedure (MIP). Hasil penelitian tersebut berupa jenis metafora berdasarkan tataran sintaksis, konseptualisaai metafora melalui pemetaan ranah sumber dan ranah sasaran, serta analisis fungsi metafora. Ditemukan 17 ranah sumber dalam penelitian tersebut, yaitu perang, tarian, perlombaan, olahraga, matematika, permainan, pertunjukan sandiwara, perdangangan dan bisnis, suhu, tubuh manusia, gerakan dana rah, api, masakan, puncak/ketinggian, warna, sakit, dan perjalanan.

Berdasarkan penelitian-penelitian sebelumnya, penelitian ini tentunya memiliki perbedaan. Penelitian ini berfokus pada penggunaan ranah sumber pada konseptualisasi metafora pascapemilihan Presiden dan Wakil Presiden tahun 2019 dalam media sosial twitter. Data diambil dari cuitan (tweet) masyarakat Indonesia mengenai kemenangan pascapemilihan Presiden dan Wakil Presiden Indonesia tahun 2019 yang dibatasi dari tanggal 17 April 2019-30 Juni 2019. Selanjutnya data yang telah terkumpul, dianalisis untuk melihat ranah sumber pada konseptualisasi kemenangan.

\section{HASIL DAN PEMBAHASAN}

Berdasarkan analisis data yang telah dilakukan, ditemukan sebanyak 112 data mengenai konseptualiasi kemenangan. Dari keseluruhan data tersebut dikategorikan menjadi 9 ranah sumber, yaitu (1) manusia; (2) bangunan; (3) makanan; (4) cahaya; (5) alat; (6) permainan dan pertandingan; (7) perjalanan; (8) harta; dan (9) agama. Intensitas penggunaan ranah sumber didominasi oleh ranah sumber manusia serta permainan dan pertandingan, sedangkan intensitas yang paling sedikit adalah ranah rumber agama dan bangunan.

Intensitas penggunaan ranah sumber dapat digunakan untuk melihat kecenderungan masyarakat Indonesia membangun konseptualisasi kemenangan pascapemilihan Presiden dan Wakil Presiden Indonesia tahun 2019 dalam media sosial twitter. Konseptualisasi kemenangan dengan ranah sumber tersebut dibangun berdasarkan lingkungan yang membentuk masyarakat atau situasi keadaan yang ada dalam masyarakat itu sendiri. Ranah sumber sangat penting untuk menentukan konseptualisasi metafora yang dibentuk dari ranah sasaran kemenangan.

\section{Ranah Sumber Manusia}

Kelas ranah sumber manusia memiliki produktivitas yang tinggi. Penggunaannya dibedakan menjadi dua bagian, yaitu bagian tubuh dan tindakan manusia. Ranah sumber manusia berdasarkan bagian tubuh misalnya jantung, sedangkan jika dilihat berdasarkan tindakan yang bisa dilakukan oleh manusia biasanya didominasi oleh kata kerja, misalnya mengumbar, merayakan. Berikut merupakan contoh data metafora menurut kategori ranah sumber manusia.

(1) C1 adalah jantung kemenangan kita Prabowo Sandi.

(2) Kemenangan yg msh premature tapi disambut gegap gempita olh pendukungnya.

(3) Prabowo, kemenangan sudah di tangan kita. 
Data (1), (2), dan (3) menunjukkan bahwa metafora jantung kemenangan, kemenangan yg msh premature, dan kemenangan sudah di tangan kita merupakan ranah sumber manusia yang berkorespondensi dengan organ-organ penting dan keadaan bayi yang lahir secara premature. Data (1) yaitu jantung kemenangan, jika diidentifikasi melalui kamus KBBI V kata jantung merupakan bagian tubuh yang menjadi pusat peredaran darah. Dari data (1) tersebut konsep abstrak kemenangan diartikan ke konsep konkret berupa jantung sebagai bagian tubuh yang menjadi pusat peredaran darah.

Data (2) menunjukkan ungkapan metaforis berupa kemenangan yg msh premature, yaitu kemenangan yang disandingkan dengan konsep prematur pada bayi. Prematur diartikan sebagai sesuatu yang belum (waktunya) masak (matang); sebelum waktunya; belum cukup bulan; pradini. Konseptualisasi kemenangan sebagai sesuatu yang prematur karena menyatakan kemenangan sebelum waktunya. Data (3) menunjukkan ungkapan metaforis berupa kemenangan yang keberadaannya sudah di tangan kita. Dalam hal tersebut kemenangan diartikan sebagai sesuatu yang bisa dirasakan oleh bagian tubuh berupa tangan yang dapat digenggam dan dirasakan

(4) Boleh menjanjikan kemenangan selepas kemusnahan dan kematian adalah mudah.

(5) Misi mereka cuma untuk mengundur pesta kemenangan para cebong sambil mengumpulkan simpati publik dengan menggiring opini mereka 'merasa' sedang dizolimi.

Kedua data (4) dan (5) merupakan contoh dari konseptualisasi kemenangan dengan ranah sumber manusia yang dapat dilihat dari tindakan yang hanya bisa dilakukan oleh manusia. Contoh data (4) menunjukkan bahwa kemenangan dinyatakan sebagai sesuatu yang dapat disandingkan dengan janji. Kata janji yang mengalami imbuhan menjadi menjanjikan, jika dilihat menurut $\mathrm{KBBI} \mathrm{V}$ berarti menyatakan kesediaan dan kesanggupan untuk berbuat sesuatu kepada orang lain. Konseptualisasi kemenangan sebagai sesuatu yang dapat dijanjikan. Data (5) menunjukkan ungkapan metaforis berupa pesta kemenangan, kata pesta jika dilihat dari KBBI V diartikan sebagai perjamuan makan minum (bersuka ria dan sebagainya); perayaan. Dalam hal ini, kemenangan dikonseptualisasikan sebagai sebuah perjamuan makan minum yang dirayakan oleh manusia (pendukung).

\section{Ranah Sumber Bangunan}

Ranah sumber bangunan merupakan sesuatu yang dibangun, dapat berbentuk bangunan rumah, gedung, atau isi yang ada di dalamnya. Ranah sumber bangunan ini juga identik dengan tempat. Berdasarkan data yang telah dianalisis, ranah sumber bangunan ini memiliki intensitas yang sangat kecil. Berikut merupakan contoh data dari konseptualiasi kemenangan dengan ranah sumber bangunan.

(6) Kasih kesempatan napa rayakan kemenangan versi dapur sendiri.

Data (6) menunjukkan ungkapan metaforis berupa kemenangan versi dapur sendiri. Dalam data tersebut, ranah sasaran kemenangan dikonsepkan sebagai bangunan, yaitu dapur. Menurut KBBI V, dapur diartikan sebagai ruang tempat memasak. Konseptualisasi kemenangan sebagai ruangan dapur tempat untuk memasak.

\section{Ranah Sumber Makanan}

Makanan sebagai ranah sumber juga ditemukan dalam konseptualisasi kemenangan. Walaupun intensitas datanya tidak banyak, ranah sumber makanan ini sangat beragam. Berikut merupakan contoh datanya.

(7) Sudahlah gak usah caper atau menjilat, masih banyak orang di TKN \& koalisi 01 yg pantas mendapat kue kemenangan.

(8) Berikan pertarungan yang keras di MK hingga kemenangan yang begitu manis, jikapun harus kalah kita tetap tertawa.

(9) Kemenangan pakde @jokowi adalah kemenangan yang murni, karena masih diharapkan dan diinginkan oleh berbagai lapisan masyarakat Indonesia.

Data (7), (8), dan (9) merupakan ungkapan metaforis dari ranah sasaran kemenangan yang diikuti ranah sumber makanan, yaitu kue, manis, dan murni. Data (7) memperlihatkan adanya ungkapan 
metaforis berupa kue kemenangan. Kata kue dalam KBBI V diartikan sebagai panganan yang dibuat dari bahan yang bermacam-macam, dapat dibuat dalam berbagai bentuk, ada yang dikukus, dogoreng, dan dipanggang. Konseptualisasi kemenangan sebagai sesuatu yang dibutuhkan oleh banyak orang, yaitu berupa panganan kue.

Contoh data (8) menunjukkan ungkapan metaforis berupa kemenangan yang disandingkan dengan kata sifat berupa manis. Kata manis dalam KBBI V diartikan sebagai rasa seperti gula. Konseptualisasi kemenangan sebagai sesuatu yang dapat dirasakan oleh mulut berupa rasa manis seperti gula. Data (9) merupakan konseptualisasi kemenangan sebagai sesuatu yang murni. Dalam KBBI $\vee$ murni diartikan sebagai sesuatu yang tidak bercampur dengan hal lain. Konsep kemenangan sebagai sesuatu yang murni yaitu tidak adanya campuran dengan hal lain.

\section{Ranah Sumber Cahaya}

Ranah sumber cahaya sebagai sesuatu yang dapat dilihat dan dirasakan oleh mata. Cahaya sebagai sebuah sinar yang terang atau berkilau. Ranah sumber ini memiliki intensitas yang kecil. Berikut merupakan contoh data dari ranah sumber cahaya.

(10) Kemenangan itu sudah terang benderang. (A070)

(11) Giliran sidang MK di gelar dan keliatan secercah cahaya kemenangan, maka berbondongbondong pula para kaum yg berkhianat dan aku ragu2 merapat dan bersiul lantang di media sosial. (A088)

Data (10) dan (11) merupakan ungkapan metaforis kemenangan sebagai ranah sasaran yang disandingkan dengan ranah sumber cahaya. Contoh data (10) menunjukkan bahwa kemenangan merupakan sesuatu yang terang benderang. Frase terang benderang merupakan gabungan dari kata terang dan benderang. Kata terang dalam KBBI V diartikan sebagai keadaan yang dapat dlihat dengan nyata dan jelas; cerah; bersinar; cahaya; dan sinar, sedangkan kata benderang diartikan sebagai terang benar(tentang cahaya, warna). Konspetualiasi kemenangan sebagai keadaan yang dapat dilihat dengan nyata dan jelas dan bersinar secara terang benar.

Data (11) merupakan konseptualisasi kemenangan dengan ranah sumber cahaya yang diidentifikasi dari secercah cahaya. Frase secercah cahaya merupakan gabungan dari kata secercah dan cahaya. Kata secercah dalam KBBI V diartikan sebagai sedikit sinar yang dapat dilihat. Itu berarti kemenangan dikonseptualisasikan sebagai sedikit sinar yang dapat dilihat.

\section{Ranah Sumber Alat}

Ranah sumber alat merupakan suatu benda yang digunakan untuk mengerjakan sesuatu maupun dipakai untuk mencapai suatu maksud tertentu. Berdasarkan data yang telah dianalisis, penggunaan ranah sumber alat memiliki intensitas yang cukup banyak. Hal tersebut dipengaruhi penggunaan alat yang tidak bisa lepas dari kebutuhan sehari-hari. Berikut ini merupakan data dengan ranah sumber alat.

(12) Kunci kemenangan kita berada di c1 asli.

(13) Kemenangan adalah hadiah.

(14) Sebagai wacana akademik dan dalam forum terbatas mungkin menarik membuat studi korelasi antara peta kemenangan Jokowi/Prabowo dg peta basis-basis pemberontakan terhadap NKRI yg pernah ada.

Data (12), (13), dan (14) merupakan bentuk dari ungkapan metaforis kemenangan sebagai ranah sasaran yang dikonsepkan melalui ranah sumber alat. Contoh data (12) menunjukkan ungkapan metaforis berupa kunci kemenangan. Kata kunci dalam KBBI V merupakan alat yang dibuat dari logam untuk membuka atau mengancing pintu dengan cara memasukkannya ke dalam lubang yang ada pada induk kunci. Konseptualisasi kemenangan yang diungkapkan sebagai kunci kemenangani merupakan alat yang digunakan untuk membuka atau mengancing pintu.

Data (13) merupakan konseptualisasi kemenangan yang diungkapkan secara metaforis sebagai kemenangan adalah hadiah. Kata hadiah dalam KBBi V diartikan sebagai sebuah pemberian berupa kenang-kenangan, penghargaan, maupun penghormatan. Dalam hal ini kemenangan 
dikonseptualisasikan menjadi sesuatu yang diberikan sebagai bentuk kenang-kenangan, penghargaan, maupun penghormatan. Contoh data (14) menunjukkan ungkapan metaforis berupa peta kemenangan. Kata peta dalam KBBI V diartikan sebagai gambar atau lukisan pada kertas dan sebagainya yang menunjukkan letak tanah, laut, sungai, gunung, dan sebagainya; wujud representasi melalui gambar dari suatu daerah yang menyatakan sifat, seperti batas daerah, sifat permukaan; denah. Berdasarkan hal tersebut, konseptualiasi kemenangan sebagai alat berupa peta yang dapat digunakan untuk melihat keadaan suatu daerah.

\section{Ranah Sumber Permainan dan Pertandingan}

Ranah sumber ini dibagi menjadi dua kategori yaitu permainan dan pertandingan. Permainan diartikan sebagai sesuatu yang digunakan untuk dipermainkan, sedangkan pertandingan merupakan perlombaan dalam olahraga yang menghadapkan dua pemain (atau regu) untuk bertanding. Ranah sumber permainan dan pertandingan dalam konseptualisasi kemenangan ini memiliki intensitas yang banyak. Berikut ini merupakan contoh data dari ungkapan metaforis mengenai kemenangan yang tergolong dalam ranah sumber permainan dan pertandingan.

(15) Goal kemenangan bukan pendahuluan.

(16) Mereka mengira 'people power' itu adlh massa anarkis seperti yg kemarin konvoi kemenangan.

Data (15) dan (16) merupakan konspetualisasi kemenangan yang dikonsepkan dalam ranah sumber permainan. Data (15) berupa goal kemenangan merupakan ungkapan metaforis. Kata goal berasal dari bahasa Inggris yang diartikan ke dalam bahasa Indonesia sebagai kata gol, yaitu tercapai maksudnya (tujuan); berhasil. Konseptualisasi kemenangan sebagai sesuatu yang harus dicapai dan berhasil. Contoh lain dari ranah sumber permainan, data (16), menunjukkan bahwa kemenangan merupakan konvoi. Kata konvoi dalam KBBI V merupakan iring-iringan mobil (kapal) dengan pengawalan bersenjata. Konseptualisasi kemenangan sebagai suatu iring-iringan dengan perngawalan bersenjata juga ditemukan dalam data tersebut.

(17) Kemenangan adalah perjuangan dari nol, melewati proses panjang dan kerja keras hingga bisa mencapai puncak.

(18) Tetapi tiba2 seorang professor bicara memetakan basis kemenangan dengan sentiment rasis.

(19) Deklarasi kemenangan adalah bentuk perang opini.

Data (17), (18), dan (19) merupakan wujud dari ranah sumber pertandingan dalam ungkapan metaforis kemenangan. Data (17) menunjukkan kemenangan diungkapkan sebagai perjuangan. Kata perjuangan dalam KBBI V diartikan sebagai usaha yang penuh dengan kesukaran dan bahaya. Dalam hal ini, kemenangan dikonsepkan sebagai sesuatu yang diusahakan penuh dengan kesukaran dan bahaya. Data (18), ungkapan basis kemenangan identik dengan ranah sumber pertandingan. Lata basis dalam KBBI V diartikan sebagai pangkalan (angkatan laut, angkatan darat, dan sebagainya) untuk melakukan operasi. Konseptualisasi kemenangan sebagai basis berupa pangkalan untuk melakukan operasi dalam sebuah pertandingan.

Contoh lain, data (19) menunjukkan ungkapan metaforis kemenangan yang disandingkan dengan perang opini. Frase perang opini dibentuk dari dua kata perang dan opini. Kedua kata tersebut jika diartikan menurut KBBI V yaitu, perang berarti pertempuran besar bersenjata antara dua pasukan (tentara, laskar, pemberontak, dan sebagainya) atau lebih, sedangkan kata opini berarti pendapat; pikiran; pendirian. Konseptualisasi kemenangan sebagai perang opini merupakan wujud dari pertempuran antara dua pasukan dalam melakukan pendapat, pemikiran, maupun pendirian.

\section{Ranah Sumber Perjalanan}

Ranah sumber perjalanan identik dengan perihal perjalanan, kepergian dari suatu tempat ke tempat yang lain, maupun jarak yang dicapai menuju suatu tempat. Dalam penelitian ini, ranah sumber perjalanan memiliki intensitas yang sangat tinggi. Pengungkapan konsep kemenangan yang dibangun oleh masyarakat melalui ranah sumber perjalanan sangat beragam. Berikut merupakan contoh datanya. 
Ranah Sumber Konseptualisasi Kemenangan Pascapemilihan Presiden dan Wakil Presiden Tahun 2019 dalam Media Sosial Twitter

(20) Perang opini, harus gencar siapa yg kuat mentalnya dia yg menang, karena hasil pemilu dan sebelum pemilu 02 selalu dilemahkan semangat juangnya, buat para elit 02 jgn gentar perjalanan kemenangan ini masih panjang prosesnya.

(21) Dia mengejar kemenangan. Dia dikejar kecurangan.

(22) Sebaliknya, memaksakan kemenangan adalah jalan besar menuju kemenangan yang mengesankan.

(23) Ubahlah kesusahan mereka dg kemenangan sebagai jalan keselamatan untuk NKRI.

Data (20) menunjukkan bahwa adanya ungkapan metaforis berupa perjalanan kemenangan ini masih panjang prosesnya. Konsep kemenangan sebagai sesuatu yang panjang prosesnya. Kata proses da;am KBBI V berarti rangkaian tindakan, pembuatan, atau pengolahan yang menghasilkan produk. Dalam hal ini ranah sumber perjalanan dalam konseptualisasi kemenangan diartikan sebagai rangkaian tindakan yang memiliki tujuan tertentu. Data (21) berupa mengejar kemenangan menunjukkan konspetualisasi dengan ranah sumber perjalanan. Kata mengejar dalam KBBI $\mathrm{V}$ berarti menyusul dengan berlari; memburu; berusaha keras hendak mencapai (mendapatkan dan sebagainya); menginginkan dengan sungguh-sungguh. Konseptualisasi kemenangan dibangun berdasarkan sesuatu yang dapat dikejar dengan berlari dan menjadi sesuatu yang diinginkan dnegan sungguhsungguh.

Contoh lain, data (22) berupa kemenangan adalah jalan besar. Frase jalan besar berasal dari dua kata yaitu jalan yang berarti tempat untuk lalu lintas orang, sedangkan besar merupakan kata sifat yang berarti lebih dari ukuran sedang. Berdasarkan arti tersebut, konseptualisasi kemenangan sebagai jalan besar merupakan wujud dari tempat untuk lalu lintas orang dengan lebih dari ukuran sedang. Data (23) berupa kemenangan sebagai jalan keselamatan. Frase jalan keselamatan berasal dari dua kata jalan dan keselamatan. Kata keselamatan dalam KBBI V berarti perihal (keadaan dan sebagainya) selamat; kesejahteraan; kebahagiaan; dan sebagainya. Konseptualisasi kemenangan sebagai perjalanan berupa jalan keselamatan yang digunakan untuk kesejahteraan dan kebahagiaan.

\section{Ranah Sumber Harta}

Ranah sumber harta diartikan sebagai barang (dapat berupa uang, emas, kertas, perak) yang menjadi kekayakaan atau milik seseorang. Harta sebagai sesuatu yang berharga dan dipertahankan bagi seseorang. Dalam penelitian ini, intensitas penggunaan ranah sumber uang dan harta yaitu sedikit. Berikut merupakan contoh data dari konseptualisasi kemenangan yang menggunakan ranah sumber tersebut.

(24) Terlalu besar risiko bagi pelaku pencurangan dengan margin kemenangan yang cukup besar.

(25) Tujuan akhirnya adalah "steal the result" yaitu mencuri kemenangan.

(26) 02 menang berdasarkan hitungan IT BPN @prabowo bertekad melawan jika kemenangan 02 dirampok.

Data (24), (25), dan (26) menunjukkan adanya ungkapan metaforis kemenangan yang dikonsepkan melalui ranah sumber harta. Data (24) berupa margin kemenangan, kata margin dalam KBBI V laba bruto; deposit atau uang muka oleh investor dengan atau tanpa makelar yang merupakan pembayaran sebagian atau harga beli saham atau komoditas. Berdasarkan hal tersebut, konseptualisasi kemenangan sebagai harta merupakan laba atau deposit uang muka oleh investor. Data (25) berupa mencuri kemenangan merupakan konseptualisasi yang dibangun oleh masyarakat mengenai kemenangan sebagai ranah sumber harta yang dapat dicuri. Kata mencuri dalam KBBI V berarti mengambil milik orang lain tanpa izin atau dengan tidak sah, biasanya dengan sembunyisembunyi. Konseptualisasi kemenangan berdasarkan arti tersebut yaitu kemenangan sebagai harta yang dapat diambil oleh orang lain tanpa izin atau dengan tidak sah.

Contoh terakhir adalah data (26) berupa ungkapan kemenangan o2 dirampok. Angka 02 merujuk pada Paslon 02, Prabowo dan Sandiaga Uno, sedangkan kata dirampok berasal dari kata dasar rampok yang jika diartikan dalam KBBI V berarti orang yang mengambil dengan paksa dan kekerasan barang milik orang. Ungkapan metaforis tersebut menunjukkan bahwa kemenangan adalah harta yang memiliki nilai sehingga ada orang yang ingin mengambil dengan paksa. 


\section{Ranah Sumber Agama}

Ranah sumber agama memiliki intensitas yang sangat kecil. Agama diartikan sebagai ajaran, sistem yang mengatur tata keimanan (kepercayaan) dan peribadatan kepada Tuhan Yang Mahakuasa. Intensitas ranah sumber agama yang sedikit dalam konseptualisasi kemenangan ini, membuktikan bahwa masyarakat tidak begitu menyangkutpautkan agama dengan isu kemenangan yang diartikan secara berbeda-beda ini. Berikut ini merupakan contoh dari data yang berhasil ditemukan.

(27) Kesyahidannya menuju kemenangan!

Data (27) merupakan satu-satunya data yang ditemukan dalam konseptualisasi kemenangan dengan ranah sumber agama. Ungkapan kesyahidannya menuju kemenangan merupakan ungkapan metaforis yang membawa unsur agama berupa kesyahidannya yang berasal dari kata dasar syahid. Kata syahid dalam KBBI V diartikan sebagai saksi (dalam usaha menegakkan atau mempertahankan kebenaran agama); orang yang mati karena membela agama. Pengungkapan metafora kemenangan dengan ranah sumber agama menunjukkan bahwa kemenangan merupakan bagian dari saksi atau orang yang mati karena membela agama.

\section{SIMPULAN}

Metafora dapat menunjukkan cara masyarakat berpikir terhadap situasi yang ada di sekitarnya. Adanya konseptualisasi dari satu masyarakat dengan masyarakat lain mengenai konsep kemenangan merupakan hasil dari cara berpikir secara kognitif. Masyarakat membangun konsep abstrak berupa kemenangan dalam media sosial twitter dengan konsep lain yang lebih konkret atau biasa disebut dengan ranah sumber. Data dalam penelitian ini diambil dari cuitan (tweet) masyarakat Indonesia yang mengguanakan media sosial twitter. Pengambilan data dibatasi pascapemilihan dari tanggal 17 April 2019 hingga 20 Juni 2019. Setelah dilakukan pengumpulan data, selanjutnya data dianalisis. Berdasarkan penelitian yang telah dilakukan, ditemukan 112 data yang diklasifikasikan menjadi 9 ranah sumber, yaitu (1) manusia; (2) bangunan; (3) makanan; (4) cahaya; (5) alat; (6) permainan dan pertandingan; (7) perjalanan;(8) harta; dan (9) agama. Intensitas penggunaan ranah sumber didominasi oleh ranah sumber manusia serta ranah sumber permainan dna pertandingan, sedangkan intensitas penggunaan ranah sumber yang paling sedikit adalah ranah sumber lingkungan alam dan ranah sumber bangunan.

\section{DAFTAR PUSTAKA}

Arifiani, Faradinna. 2015. Metafora dalam Wacana Politik: Studi Kasus Pemilihan Presiden dan Wakil Presiden Republik Indonesia tahun 2014 di Majalah Tempo dan Surat Kabar Kompas. (Tesis Fakultas Ilmu Budaya, Universitas Gadjah Mada). Yogyakarta. Tidak diterbitkan.

Arimi, Sailal. 2015. Linguistik Kognitif: Sebuah Pengantar. Yogyakarta: A.com Press.

Kovecses, Zoltan. 2010. Metaphor: A Pratical Introduction. New York: Oxford University Press, Inc. Lakoff, George \& Mark Johson. 2003. Metaphors We Live By. Chicago: University of Chicago Press.

Mudrika, Andi. 2016. Penggunaan Metafora dalam Wacana Pemilihan Presiden Amerika Serikat Tahun 2012 pada Surat Kabar "The New York Times". (Tesis Fakultas Ilmu Budaya, Universitas Gadjah Mada). Yogyakarta. Tidak diterbitkan.

Yonatri, Agiana Eka. 2016. Metafora Konseptual tentang Pendidikan dalam Bahasa Inggris. (Tesis Fakultas Ilmu Budaya, Universitas Gadjah Mada). Yogyakarta. Tidak diterbitkan. 